\title{
ANALISIS IMPLEMENTASI SISTEM INFORMASI MANAJEMEN DAERAH (SIMDA) PADA DINAS PERUMAHAN RAKYAT DAN KAWASAN PERMUKIMAN (DPRKP) KABUPATEN MAGELANG
}

\author{
Intan Shinta Wanti ${ }^{1}$, Ghina Fitri Ariesta Susilo ${ }^{2}$ \\ Program Studi Akuntansi, Fakultas Ekonomi, Universitas Tidar \\ 1intanshinta7@gmail.com \\ $\underline{2}$ ghinafitri.ariesta@untidar.ac.id
}

\begin{abstract}
ABSTRAK
Tujuan penelitian ini adalah untuk memberi gambaran tentang pengimplementasian Sistem Informasi Manajemen Daerah (SIMDA) keuangan pada Dinas Perumahan Rakyat dan Kawasan Permukiman (DPRKP) Kabupaten Magelang. Penelitian ini termasuk dalam kategori kualitatif deskriptif dengan menggunakan data primer dan data sekunder. Teknik pengumpulan data primer dilakukan dengan observasi dan wawancara. Hasil penelitian menunjukkan bahwa DPRKP Kabupaten Magelang telah mengimplementasikan Sistem Informasi Manajemen Daerah (SIMDA) Keuangan sejak Januari tahun 2015.
\end{abstract}

Kata Kunci: Sistem Informasi Manajemen, Sistem Informasi Manajemen Daerah (SIMDA) Keuangan, Penerapan SIMDA

\section{ABSTRACT}

The purpose of this research is to give an overview of the implementation of regional management information system (SIMDA) for finance at Dinas Perumahan Rakyat dan Kawasan Permukiman (DPRKP) of Magelang Regency. This research is included in qualitative descriptive categories by using primary data and secondary data. Primary data collection techniques are conducted with observation and interview. The results showed that DPRKP of Magelang Regency has implemented regional management information system (SIMDA) finance since January 2015.

Keywords: Management information system, Management Information System (SIMDA) finance, implementation of SIMDA 


\section{PENDAHULUAN}

\subsection{Latar Belakang}

Sistem pengolahan serta pelaporan data keuangan yang ada pada suatu entitas kini telah berkembang. Perkembangan sistem pengolahan data keuangan pada suatu entitas ini dipengaruhi oleh kemajuan teknologi informasi dan komunikasi. Kemajuan teknologi ini dimanfaatkan oleh pemerintah untuk mengembangkan dan meningkatkan kemampuan dalam melakukan pengelolaan keuangan guna menciptakan tata pemerintahan yang baik. Dalam UU Nomor 33 tahun 2004 menyebutkan bahwa transparansi dan akuntabilitas serta perumusan kebjakan fiskal dapat meningkat dengan adanya sistem informasi keuangan daerah.

Salah satu cara memanfaatkan kemajuan teknologi yaitu dengan adanya SIMDA Keuangan yang dikembangkan oleh BPKP (Badan Pengawas Keuangan dan Pembangunan). SIMDA ialah sistem yang dimanfaatkan dalam membantu penyelenggaraan pengelolaan keuangan pada suatu instansi agar terciptanya suatu laporan keuangan yang relevan,akuntabilitas, dan transparansi. Dinas Perumahan Rakyat dan Kawasan Permukiman (DPRKP) Kabupaten Magelang adalah salah satu diantara beberapa Satuan Kerja Pemerintah Daerah (SKPD) yang sudah mengimplementasikan SIMDA sejak Januari 2015.

DPRKP mengimplementasikan SIMDA pada beberapa prosedur yaitu prosedur penganggaran, prosedur penatausahaan penerimaan kas, prosedur pengelolaan pengeluaran kas, prosedur akuntansi dan pelaporan. Pada setiap Satuan Kerja Perangkat Daerah (SKPD) yang ada di Kabupaten Magelang juga telah menerapkan pelaporan keuangan berbasis aplikasi yaitu dengan SIMDA. Dinas Pendapatan, Pengelolaan Keuangan dan Aset Daerah (DPPKAD) telah mengadakan Bimtek aplikasi SIMDA pertangungjawaban keuangan yang dilaksanakan sejak awal penerapan SIMDA tahun 2015. Bimtek ini diikuti oleh seluruh petugas akuntansi SKPD di Kabupaten Magelang, admin dan Pejabat Pengelola Keuangan Daerah (PPKD).

Penelitian ini bertujuan untuk mengetahui implementasi pelaporan keuangan dengan menggunakan aplikasi yang dikenal dengan SIMDA. Adanya aplikasi SIMDA Keuangan ini diharapkan agar mempermudah tugas pelaporan keuangan daerah, menghasilkan 
informasi laporan keuangan dan informasi keuangan lainnya dengan kualitas yang relevan, akurat dan ketepatan waktu yang lebih baik dari sebelumnya. Adanya penelitian ini guna mengetahui apakah aplikasi SIMDA yang diterapkan pada DPRKP Kabupaten Magelang tersebut sudah diterapkan dengan baik dan sesuai dengan yang diharapkan oleh Pemerintah Daerah Kabupaten Magelang.

\section{TINJAUAN PUSTAKA}

\subsection{Sistem Informasi Manajemen (SIM)}

Sistem Informasi Manajemen (SIM) terdiri dari sekelompok manusia dan sumber daya modal yang berkewajiban untuk mengumpulkan dan mengolah informasi agar menghasilkan keluaran yang bermanfaat untuk manajemen perencanaan dan pengendalian di suatu organisasi (Cushing, 2005). SIM ialah sebuah kombinasi antara sumber daya manusia dan teknologi informasi yang saling berpadu dalam memilih, menyimpan, dan mengolah, serta menarik kembali data yang dimanfaatkan untuk proses pengambilan keputusan di suatu perusahaan (Rochaety, dkk., 2012). Perencanaan, pengendalian serta proses pengambilan keputusan dapat lebih relevan dengan adanya SIM ini.

\subsection{Sistem Informasi Manajemen Daerah (SIMDA)}

Sistem Informasi Manajemen Daerah (SIMDA) adalah aplikasi yang dapat membantu proses pelaporan keuangan suatu instansi. SIMDA ini dikembangkan oleh Badan Pengawasan Keuangan dan Pembangunan untuk pengelolaan keuangan daerah yang diterapkan pada pemerintah daerah. SIMDA ialah aplikasi berbentuk database yang tujuannya memudahkan pengelolaan keuangan daerah di lingkungan Satuan Kerja Perangkat Daerah (SKPD). Dalam mengembangkan SIMDA, sistem pengendalian internal pemerintah juga harus diperhatikan dan diterapkan (Budiman, dkk., 2013)

Output yang dihasilkan oleh SIMDA di setiap SKPD lebih terintegrasi sehingga proses pengambilan keputusan menjadi sangat terbantu. Dengan adanya SIMDA maka proses pelayanan masyarakat dan administrasi pemerintahan dapat terpenuhi secara cepat, tepat, lengkap, akurat (Sepang, 2017). SIMDA ini terbagi menjadi beberapa 
kelompok yaitu SIMDA Pendapatan, SIMDA Keuangan, SIMDA Gaji, dan SIMDA BMD (Barang Milik Daerah)

\section{METODE PENELITIAN}

Penelitian ini termasuk dalam kategori kualitatif deskriptif dengan menggunakan data primer dan data sekunder. Teknik pengumpulan data primer dilakukan dengan teknik observasi dan wawancara yang didapat langsung dari DPRKP dan data sekunder yang diperoleh dari beberapa jurnal terdahulu yang berkaitan dengan SIMDA. Wawancara langsung dilakukan dengan Bendahara, Kepala Sub Bagian Umum dan Kepegawaian, dan Ka Sub Bag Program dan Keuangan DPRKP. Penelitian dilaksanakan pada tanggal 13 Januari sampai dengan 13 Februari 2020 di DPRKP Kabupaten Magelang Jl. Soekarno Hatta No.9, Patran, Sawitan, Mungkid, Magelang, Jawa Tengah 56511.

\section{HASIL DAN PEMBAHASAN}

\subsection{Gambaran Umum}

SIMDA ialah aplikasi yang dimanfaatkan sebagai pengelolaan keuangan yang terintegrasi sehingga tata kelola keuangan sampai pada pelaporan keuangan menjadi lebih relevan dan dapat digunakan untuk pengambilan keputusan di suatu entitas. SIMDA juga digunakan sebagai alat pengontrol berbagai aktivitas yang ada di SKPD, selain itu SIMDA juga dimanfaatkan dalam proses pembuatan laporan keuangan.

Dinas Perumahan Rakyat dan Kawasan Permukiman (DPRKP) Kabupaten Magelang adalah SKPD yang sudah mengimplementasikan SIMDA sejak 2015 sebagai sarana pencatatan pengelolaan keuangan. Hal tersebut seperti yang telah dijelaskan langsung oleh Ibu Trintana Paulina, SH sebagai Kepala Sub Bagian Umum dan Kepegawaian yaitu:

"Dinas Perumahan Rakyat dan Kawasan Permukiman (DPRKP) ini merupakan salah satu SKPD ( Satuan Kerja Perangkat Daerah) yang sudah menggunakan aplikasi SIMDA Keuangan ini sejak tahun 2015. Sebelum menerapkan aplikasi SIMDA, proses 
pencatatan pelaporan keuangan dilakukan secara manual, butuh beberapa waktu untuk menyesuaikan atau beradaptasi dengan perubahan sistem pencatatan pelporan keuangan dari yang semula manual menjadi berbasis aplikasi yaitu SIMDA" (Informan 1)

\subsection{Implementasi Sistem Informasi Manajemen Daerah (SIMDA)}

Pengimplementasian atau penerapan SIMDA ini sangat membantu dalam merealisasikan rancangan yang sudah di buat dalam Rancangan Kerja Anggaran. Selain itu, penerapan SIMDA juga membantu proses pelaporan keuangan menjadi lebih terintegrasi dengan lebih efisien. Keberadaan data dan informasi menjadi penting untuk bahan evaluasi dan peningkatan kinerja dalam mengelola Keuangan DPRKP. Penerapan SIMDA yang ada pada DPRKP berdasarkan hasil wawancara dengan Ibu Lilis Setiawati yang menjabat sebagai Bendahara sekaligus operator SIMDA yaitu:

"DPRKP menerapkan aplikasi SIMDA ini dalam proses akuntansi mulai dari proses penganggaran, penerimaan kas, pengeluaran kas, sampai pada pelaporannya. Program SIMDA ini digunakan untuk pengelolaan keuangan yang ada pada Dinas Perumahan Rakyat dan Kawasan Permukiman (DPRKP) Kabupaten Magelang secara terintegrasi, dengan adanya sistem ini sangat membantu dalam proses akuntansi yang ada pada dinas ini" (informan 2).

Selain itu, informasi lain dari Ibu Lilis Setiawati selaku bendahara sekaligus operator SIMDA pada DPRKP mengenai proses akuntansi yang ada pada dinas tersebut. Berikut adalah langkah-langkah dalam proses akuntansinya:

1. Membukukan ke dalam Buku Kas Umum

a. Data Entry $\rightarrow$ SKPD $\rightarrow$ Bendahara

b. Bukti Uang Persediaan (UP) / Ganti Uang (GU) 


\begin{tabular}{|l|l|l|l|l|l|}
\hline No Bukti & & & & \multicolumn{2}{|l|}{} \\
\cline { 1 - 4 } Tanggal Bukti & Tunai & & Bank & Nama Penerima & \\
\hline Cara Pembayaran & & & & Alamat & \\
\hline Rekening & & & & & \\
\hline Nilai & & & & & \\
\hline Keterangan & & & & \\
\hline
\end{tabular}

c. No. Bukti $=$ BPK-GU/001/1.04.001/2020 (Nomor berurutan 001, 002, 003, sampai dengan semua pengajuan SPJ yang masuk)

d. Jika ada pajak yang dikenakan maka masuk ke Bukti Pengeluaran kemudian pilih jenis pajak dan masukkan jumlah pajak yang dikenakan.

2. Tutup Buku

a. Data Entry $\rightarrow$ SKPD $\rightarrow$ Bendahara $\rightarrow$ Pengeluaran $\rightarrow$ SPJ $\rightarrow$ Tambah

\begin{tabular}{|l|l|l|}
\hline \multicolumn{1}{|c|}{ No. SPJ } & \multicolumn{1}{|c|}{ SPJ-GU/..../1.04.011/2020 } & \multicolumn{1}{c|}{ Keterangan } \\
\hline Tanggal SPJ & Tanggal akhir bulan tutup kas & Pengajuan GU....Bulan....2020 \\
\hline No. BKU & Otomatis & \\
\hline
\end{tabular}

b. Simpan $\rightarrow$ Klik Rincian Belanja $\rightarrow$ Masukkan satu persatu rincian belanja lalu simpan semua sampai terbukukan.

3. Pembuatan SPP

a. Data Entry $\rightarrow$ SKPD $\rightarrow$ Tata Usaha $\rightarrow$ Pengesahan SPJ $\rightarrow$ Tambah

\begin{tabular}{|l|l|l|l|}
\hline No.SPP & SPJ-GU/..../1.04.011/2020 & Penerima \\
\hline Tanggal SPP & Sesuai pengajuan SPJ & Nama & Dprkp Kab Magelang \\
\hline Jenis SPP & Ganti Uang Persediaan (UP) & Alamat & $\begin{array}{l}\text { Jl. Soekarno Hatta No } \\
\text { 9 Kota Mungkid }\end{array}$ \\
\hline \multirow{2}{*}{ Uraian } & $\begin{array}{l}\text { Pengajuan } \\
\text { GU...Bulan...Tahun }\end{array}$ & Bank & Bank Jateng \\
\cline { 3 - 4 } & & RPWP & \\
\cline { 3 - 4 } & & & \\
\hline
\end{tabular}

b. Simpan data

4. Verifikasi SPP 
a. Data Entry $\rightarrow$ SKPD $\rightarrow$ Tata Usaha $\rightarrow$ Verifikasi SPP $\rightarrow$ GU $\rightarrow$ Klik Status $\rightarrow$ Pilih ke status Final $\rightarrow$ Proses

\subsection{Manfaat SIMDA}

Aplikasi SIMDA yang diterapakan Dinas Perumahan Rakyat dan Kawasan Permukiman (DPRKP) untuk pengelolaan keuangan menjadi lebih terintegrasi, pengendalian transaksi terjamin, efisien dalam waktu, tenaga dan biaya, serta, akurat dalam menghasilkan informasi keuangan. Selain itu penerapan aplikasi ini dapat meningkatkan kompetensi dan kapasitas SDM yang ada pada pada SKPD di Kabupaten Magelang. Dinas Pendapatan, Pengelolaan Keuangan dan Aset Daerah (DPPKAD) telah mengadakan Bimtek aplikasi SIMDA pertangungjawaban keuangan yang dilaksanakan sejak awal penerapan SIMDA. Bimtek ini diikuti oleh seluruh petugas akuntansi SKPD di Kabupaten Magelang, admin dan Pejabat Pengelola Keuangan Daerah (PPKD). Hal ini dilaksanakan agar para petugas akuntansi SKPD dapat memahami dan bisa mengerjakan laporan keuangan menggunakan aplikasi SIMDA pertanggungjawaban keuangan dengan baik. Selain memiliki manfaat yang telah penulis jelaskan tersebut, penerapan SIMDA dalam proses pelaporan data keuangan ini juga guna mematuhi peraturan perundang undangan yang berlaku seperti Undang-undang nomor 17 tahun 2003 tentang Keuangan Negara, Undang undang nomor 1 tahun 2004 tentang perbendaharaan Negara, Permendagri 13 tahun 2006 tentang Pedoman Pengelolaan Keuangan Daerah, dan peraturan perundang undangan lain yang berkaitan dengan pengelolaan keuangan daerah.

\subsection{Pengendalian Internal SIMDA Keuangan}

DPRKP mengimplementasikan SIMDA keuangan dalam melaksanakan proses penganggaran, proses penatausahaan, hingga proses akuntansi dan pelaporannya. Dalam menerapkan pelaporan keuangan berbasis aplikasi tentunya membutuhkan suatu pengendalian internal. Pengendalian internal yang diterapkan dalam dinas ini yaitu pengendalian akses dan wewenang serta pengendalian keamanan. Berikut hasil wawancara langsung dengan Bapak Andi Prastowo yang menjabat sebagai Kepala Sub Bagian Program dan Keuangan mengenai pengendalian internal yang digunakan: 
"Dalam menerapkan SIMDA ini dinas menerapkan beberapa pengendalian internal diantaranya pengendalian akses dan wewenang, dalam pengendalian akses dan wewenang ini diberlakukannya pembatasan akses dalam penggunaaan aplikasi SIMDA ini seperti membatasi siapa saja yang dipercaya mengoperasikan SIMDA sesuai dengan tugas dan tanggung jawab. Pada dinas ini yang dipercaya mengoperasikan hingga mengolah data yaitu Ibu Lilis Setyowati selaku bendahara Dinas Perumahan Rakyat dan Kawasan Permukiman (DPRKP). Kemudian pengendalian internal lainnya yang diterapkan yaitu pengendalian keamanan, hal ini tentunya berkaitan dengan keamanan data sehingga pada setiap login aplikasi SIMDA harus menggunakan username dan password yang tentunya berbeda pada setiap SKPD”

\section{KESIMPULAN}

Penelitian ini menghasilkan kesimpulan yaitu DPRKP Kabupaten Magelang telah mengimplementasikan SIMDA sebagai aplikasi pengolah data keuangan agar lebih terintegrasi dari prosedur penganggaran, penatausahaan, sampai proses akuntansi dan pelaporannya. SIMDA yang diterapkan tersebut sangat memberikan manfaat dalam proses pelaporan keuangan tersebut. Kedua, Dengan adanya SIMDA ini pelaporan keuangan yang sebelumnya berbasis manual menjadi berbasis aplikasi sehingga lebih terintegrasi, efektif, dan efisien dalam hal waktu, biaya, maupun tenaga. Selain itu, DPRKP juga menerapkan beberapa pengendalian internal yaitu Pengendalian Akses dan Wewenang, dan Pengendalian Keamanan.

\section{KETERBATASAN DAN SARAN}

Penelitian ini dilakukan dengan metode kualitatif sehingga tidak terdapat rumus pasti dalam desain dari penelitian ini sehingga penelitian baru bisa didapat pada saat penelitian ini berakhir. Selain itu pengalaman sumber informan sangat diperlukan untuk 
mendapatkan hasil yang sesuai. Peneliti perlu menemukan informan sesuai dengan pembahasan dalam penelitian. Jika penulis kurang tepat dalam menentukan informan yang sesuai dengan permasalahan penelitian, maka hasil penelitian yang didapatkan tidak akan relevan. Selain itu penelitian dilakukan dengan cara wawancara langsung dengan pihak dari DPRKP sehingga penelitian ini sangat tergantung kepada pernyataan yang diberikan oleh informan. Agar informasi yang diperoleh benar-benar relevan maka dilakukan proses pengecekan, yaitu pengecekan metode dan sumber. Pengecekan dilakukan dengan dua metode, yaitu metode observasi dan wawancara. Sedangkan pengecekan sumber dengan memastikan data dengan opini dari informan yang berbeda. Selain itu keterbatasan yang dialami oleh penulis yaitu keterbatasan waktu dalam proses penelitian yaitu hanya dilakukan selama 1 bulan saja. Selain itu dikarenakan penelitian ini bersifat kualitatif maka desain penelitian sulit direplikasi untuk penelitan di lokasi lain.

Berdasarkan hasil penelitian ini, penulis ingin memberikan saran bagi penelitian selanjutnya yang tertarik untuk melakukan penelitian mengenai SIMDA, yaitu sebagai berikut:

1. Hasil penelitian ini bisa dimanfaatkan untuk bahan referensi dan bahan perbandingan penelitian selanjutnya.

2. Peneliti selanjutnya diharapkan memanfaatkan lebih banyak sumber maupun referensi yang berhubungan dengan SIMDA agar mendapatkan hasil yang lebih baik.

3. Penelitian selanjutnya bisa menggunakan metode kuantitatif agar hasilnya bisa lebih di generalisasi.

\section{DAFTAR PUSTAKA}

Badan Pengawasan Keuangan dan Pembangungan. (n.d.). Retrieved from http://www.bpkp.go.id/sakd/konten/333/versi-2.1.bpkp

Dewi, N. C., \& Mariska, S. (2018). Analisis Penerapan Sistem Informasi Manajemen Daerah (SIMDA) Keuangan Pada Pemerintahan Kota Pariaman. Al-Masraf: Jurnal Lembaga Keuangan dan Perbankan, 3(1), 63-70. 
DPRKP Pemerintah Kabupaten Magelang. (n.d.). Retrieved from https://dprkp.magelangkab.go.id/

Hardjanto, K. (2019). Implementasi Sistem Informasi Manajemen Daerah (Simda) Keuangan Berbasis Akrual Pada Dinas Pertanian Dan Pangan Kota Magelang. Jurnal Teknik Informatika, 12(1), 11-20.

Hertanto, Y., Domai, T., \& Amin, F. (2017). Penerapan Sistem Informasi Manajemen Daerah (SIMDA) Keuangan terhadap Efektivitas Pelaporan Keuangan (Studi pada Badan Pengelolaan Keuangan dan Aset Daerah di Kabupaten Blitar). Publisia: Jurnal Ilmu Administrasi Publik, 2(1), 15-24.

Inayah, R., Hakiki, A., \& Relasari, R. (2016). Analisis Sistem Informasi Manajemen Daerah (Simda) Keuangan pada Dinas Pendapatan, Pengelolaan Keuangan dan Aset Daerah (Ppkad) Kabupaten Lahat. Akuntabilitas, 10(2), 167-176.

Monica, S. G., Saerang, D. P. E., \& Pangerapan, S. (2017). Penerapan Sistem Informasi Manajemen Daerah (SIMDA) Barang Milik Daerah pada Badan Pengelola Keuangan dan Aset Daerah Kota Manado. Going Concern: Jurnal Riset Akuntansi, 12(2).

Nugraha, H. A., \& Astuti, Y. W. (2013). Analisis Penerapan Sistem Informasi Manajemen Keuangan Daerah (Simda Keuangan) Dalam Pengolahan Data Keuangan Pada Organisasi Pemerintah Daerah (Studi Kasus Pada Dinas Kesehatan Kabupaten Nganjuk). Jurnal Akuntansi Aktual, 2(1), 25-33.

Ole, H. R. (2014). Analisis Implementasi Sistem Informasi Manajemen Daerah (SIMDA) Terhadap Kualitas Laporan Keuangan SKPD (Studi Kasus Pada Dinas PPKAD Kabupaten Minahasa Tenggara). Jurnal Accountability, 3(2), 1-15.

Pilat, J. J., Sondakh, J. J., \& Manossoh, H. (2016). Analisis Penerapan Sistem Informasi Manajemen Daerah (SIMDA) Keuangan Dalam Pengelolaan Keuangan Daerah pemerintah Kota Manado. Jurnal Accountability, 5(2), 72-83.

Rahantoknam, T. A., Tinangon, J. J., \& Mawikere, L. M. (2017). Analisis Penerapan Sistem Informasi Manajemen Daerah (SIMDA) Keuangan Pada Badan Keuangan dan Aset Daerah Kabupaten Maluku Tenggara. Going Concern: Jurnal Riset Akuntansi, 12(2). 